\section{Consumption of sugar-rich food products among Brazilian students: National School Health Survey (PeNSE 2012)}

\author{
Consumo de alimentos ricos em açúcar entre \\ estudantes brasileiros: Pesquisa Nacional de \\ Saúde do Escolar (PeNSE 2012)
}

\author{
Consumo de alimentos ricos en azúcar entre \\ estudiantes brasileños: Encuesta Nacional de \\ Salud Escolar (PeNSE 2012)
}

Nathália Luíza Ferreira 1 Rafael Moreira Claro 1 Aline Cristine Souza Lopes 1

\section{${ }^{1}$ Universidade Federal de Minas Gerais, Belo Horizonte, Brasil. \\ Correspondence \\ A. C. S. Lopes \\ Universidade Federal de \\ Minas Gerais \\ Av. Alfredo Balena 190, Belo Horizonte, MG 30130-100, \\ Brasil. \\ aline@enf.ufmg.br}

\begin{abstract}
This study aimed to analyze the consumption of high-sugar foods by Brazilian schoolchildren and to identify associated factors, based on data from the National School Health Survey (PeNSE 2012). Consumption of these foods was classified as: do not consume sweets and soft drinks regularly; consume sweets or soft drinks regularly; and consume sweets and soft drinks regularly. Its association with sociodemographic information, eating habits, and family contexts were investigated via multiple ordinal regressions. Regular consumption of sweets and/or soft drinks was reported by $19.2 \%$ and $36.1 \%$ of adolescents, respectively, and higher prevalence was associated with female gender, age 14-15 years, higher maternal education, not living with the mother and father, not eating meals with the parents, eating while watching TV, and longer TV time. Nearly one-fifth of adolescents regularly consumed sweets and soft drinks, which was associated with socio-demographic and behavioral factors that should be targeted in order to improve their food consumption.
\end{abstract}

Adolescent Nutrition; School Health; Food Consumption; Sugar; Soft Drinks

\section{Resumo}

Objetivou-se analisar o consumo de alimentos ricos em açúcar entre estudantes brasileiros $e$ identificar seus fatores associados. Utilizaramse dados da Pesquisa Nacional de Saúde do Escolar (PeNSE 2012). O consumo desses alimentos foi classificado como: não consomem guloseimas/refrigerantes regularmente; consomem guloseimas ou refrigerantes regularmente; consomem guloseimas e refrigerantes regularmente. Fatores sociodemográficos, alimentares e familiares associados foram avaliados por regressão ordinal múltipla. O consumo regular de guloseimas elou refrigerantes foi relatado por 19,2\% e 36,1\% dos adolescentes, respectivamente, sendo mais prevalente entre estudantes do sexo feminino, com 14-15 anos de idade, com maior escolaridade materna, que não viviam com a mãe e o pai, que não realizam as refeições com os pais, que comiam assistindo TV e que passavam mais tempo diante da TV. Quase 1/5 dos adolescentes consumia guloseimas e refrigerantes regularmente, condição associada a fatores sociodemográficos e comportamentais, os quais devem ser priorizados visando a melhorar seu consumo alimentar.

Nutrição do Adolescente; Saúde Escolar; Consumo de Alimentos; Açúcar; Refrigerantes 


\section{Introduction}

Adolescence is a period characterized by intense behavioral, social, emotional, psychological and physical changes, with accelerated growth rates, that result in increased energy and nutrient requirements 1 . For these requirements to be met, the diet must be both quantitatively and qualitatively adequate. However, adolescents report elevated frequency of consumption of ultra-processed food, rich in calories, sugar and fat, and poor in vitamins, minerals, and fibers 2,3 .

Among ultra-processed foods, the excessive intake of sweets, deserts and sugar sweetened beverages among adolescents stands out as a major health issue in several countries 4,5,6. In the United States, male adolescents have an average daily consumption of soft drinks of $700 \mathrm{~mL}$, and females, $350 \mathrm{~mL}$ 5. In Brazil, the average consumption of soft drinks among adolescents is $123.7 \mathrm{~mL}$, making it one of the food products with the highest individual contribution to total ingested calories 7 .

It is known that this kind of habit leads to a predisposition towards dental cavities, as well as to overweight and comorbidities such as diabetes mellitus and other cardiovascular disease risk factors 8 , both in the short and long term, since habits that are consolidated in this period usually remain through adult life 5,9,10,11,12. These and other consequences justify a recent recommendation by the World Health Organization (WHO), published in Guideline: Sugars Intake for Adults and Children 13, regarding the need to reduce consumption of sugars at all stages of life. In this context, identifying factors associated with this consumption is essential to achieve this goal and so prevent the current and future occurrence of these diseases among adolescents 5 .

Socio-demographic and economic factors have been associated with the consumption of sugar-rich food products, as well as with the risk of developing health problems in adolescence. Among these factors, age, gender, ethnicity/skin color, socioeconomic status and parental education have been explored in the literature about adolescents' health, and this research is considered essential to ensure a better understanding of the determinants of dietary intake and other lifestyle habits in this phase 14 .

Moreover, living with and having meals with parents can play an important role in the protection against risk situations among adolescents, including issues associated with food consumption $3,14,15$. Screen time has been associated with increased consumption of foods with high energy density and with the habit of eating while watching TV, factors that can promote consump- tion of sugar-rich food products 16,17. From a public policy perspective, the identification of factors associated with excessive consumption of sugar-rich food products can contribute to the planning of specific actions targeting population risk characteristics.

However, studies conducted in different countries, including Brazil, have shown conflicting results regarding the association between excessive consumption of sugar-rich food products by adolescents and gender, age and type of school $5,7,9,18,19$. On the other hand, aspects such as nutritional status, the habit of eating while watching TV, time spent watching TV, the availability of such foods at school or at home, inadequate eating habits among family and friends, and having meals with parents are more consistently associated with consumption of these foods 5,7,18,20. Furthermore, there are no national studies that analyzed the prevalence of combined consumption of sweets and soft drinks among adolescents living in urban and rural areas in Brazil as well as the factors associated with its consumption. Therefore, this study aims to analyze the consumption of sugar-rich food products in a representative sample of Brazilian adolescents and identify socio-demographic, family and behavioral factors associated with this consumption.

\section{Materials and methods}

\section{Sampling and data collection}

In this study, we used data from the National School Health Survey (PeNSE 2012) conducted by a partnership between the Brazilian Institute of Geography and Statistics (IBGE) and the Brazilian Ministry of Health between April and September 2012. This is a cross-sectional study developed from a representative sample of ninth grade students living in all regions of Brazil, including urban and rural areas and attending public and private schools. The choice of the ninth grade (the final year of Primary School in Brazil) as a focus of the research was based on the definition of the minimal level of education required for a student to be able to answer questionnaires. Moreover, it captures the age range between 13 and 15 years, considered by the WHO as reference for this group 15 .

In PeNSE 2012, the sampling plan was different for the Brazilian capitals and the Federal District, compared with for other municipalities. The capitals and Federal District $(n=27)$ corresponded to the sampling strata in the first sampling plan, while for the other municipalities the sample strata consisted of the five major 
geographical areas of Brazil. In each sample strata formed by the capitals and Federal District a sample of schools (primary sampling unit - PSU) was selected, whose information was obtained from the 2010 School Census conducted by the Brazilian Ministry of Education. These schools were visited to list the classes in ninth grade. Then classes were selected (secondary sampling unit - SSU) in each school, and all students in these classes were invited to participate in the study. For the others cities, a new selection stage was considered, corresponding to groups of municipalities, united according to homogeneity and neighborhood criteria, in order to obtain groups composed of 300 to 600 classes. A sample of municipality groups was selected for each region of Brazil (PSU), from which the schools were selected (SSU), and classes (tertiary sampling unit - TSU), whose students were asked to answer the questionnaire 15 .

A total of 2,842 schools and 4,091 classes were evaluated. Among the 110,873 students invited to take place in the study, 1,651 (1.5\%) refused to participate and $118(0.1 \%)$ adolescents did not answer questions regarding gender and/or age, and were therefore excluded from the database used in the preparation of PeNSE. Moreover, $378(0.4 \%)$ students that did not answer questions about consumption of sweets and/or soft drinks were excluded from the present study. Among these, there was a higher proportion of boys [59.7\% (51.1-67.7) vs. $47.8 \%(45.8-49.8)]$ and of students aged $\geq 16$ years $[22.3 \%(14.1-33.4)$ vs. $13.2 \%$ (9.1-18.7)] compared to the population who answered the questions about sugar-rich food products. Thus the final number of participants was 108,726 adolescents. Moreover, $18.4 \%$ of students did not know the level of education of their mothers. Due to its high percentage for this question, the answer "do not know" was considered among the categories of analysis for the "maternal education" variable. Further details concerning sampling can be found in the original publication of PeNSE 201215.

Data collection was performed with a self-reported questionnaire available as a smartphone application divided into modules concerning distinct topics such as diet; socio-demographic data; occupation; physical activities; body image; consumption of alcohol, cigarettes, and other drugs; oral health; hygienic habits; sexual behavior; violence and accidents; support network (family and friends); asthma; and anthropometry (self-reported weight and height) 15 .

\section{Data organization}

The consumption of sugar-rich food products was obtained from two questions: "In the last 7 days, on how many days did you eat sweets (sweets, candies, chocolate, chewing gum, bonbons, or lollipops)?" and "In the last 7 days, on how many days did you drink soft drinks?". The frequency of consumption of sweets and/or soft drinks was estimated, with the consumption on five or more days per week considered regular, in accordance with indicators proposed by PeNSE 15 . The outcome variable was the frequency-combined intake of these foods in the last 7 days, classified as "Do not consume sweets and soft drinks regularly" (four days or less per week); "Consume sweets or soft drinks regularly"; and "Consume sweets and soft drinks regularly" (five or more days per week).

The socio-demographic information analyzed included gender (male; female); participant's age ( $\leq 13 ; 14 ; 15 ; \geq 16$ years); skin color (white; black; brown; Asian; American Indian); maternal education $(\leq 8 ; 9-11 ; \geq 12$ years; do not know) and administrative classification of the school (public; private). Family-related and behavioral variables included living with their mother and father (yes; no); the habit of having meals with parents/guardians (regular: five or more days per week; irregular: four days or less per week); eating meals while watching the television (no; yes); and time spent watching TV $(\leq 2$; $3-4 ; \geq 5$ hours per day 14 ).

\section{Data analysis}

The population evaluated was initially described by its socio-demographic, behavioral, and family-related characteristics. The consumption of sugar-rich food products was depicted according to the covariates. The individual and combined consumption of soft drinks and sweets were identified.

The association between consumption of sugar-rich food products and socio-demographic, behavioral, and family-related characteristics was initially verified using the chi-square test, with Bonferroni correction. Differences were considered significant when $\mathrm{p}$-values were less than 0.017 [(0.05 (significance level)/3 (number of comparison groups)]. We used simple ordinal regression (proportional odds model - POM) in order to obtain the crude odds ratio (OR) and respective $95 \%$ confidence intervals $(95 \% \mathrm{CI})$, in addition to multiple ordinal regression to identify the factors associated with the outcome variable by backward method. The covariates with a significance level of $5 \%$ were retained in the final 
models. When POM is employed, it is assumed that OR are similar for all the categories under comparison, which corresponds to the proportional odds assumption. To interpret the model, we compared values smaller or equal to a certain category of outcome variable in relation to higher values 21 . All statistical analyses were performed using Stata software (version 12.1; StataCorp LP, College Station, USA) and commands were performed taking into account the complex sample design of PeNSE. In the final model 108,043 students who presented complete information about the investigated variables were considered.

This study was conducted according to the guidelines laid down in the Declaration of Helsin$k i$. The National Ethics Research Committee of the Brazilian Ministry of Health (issue n. 11,537) approved all procedures involving human subjects/patients. All students reported their consent to participate in the survey by filling out a form in the questionnaire that was administered via smartphone.

\section{Results}

The majority of the students evaluated were female $(52.2 \%)$, whose mothers had less than 12 years of education (68.3\%), attended public schools $(82.8 \%)$, ate meals while watching television $(81.1 \%)$ and spent more than two hours per day watching TV $(63.7 \%)$. More than $45 \%$ of students were aged 14 (45.6\%), most reported their skin color to be brown (42.2\%), $62.2 \%$ of participants lived with their mother and father and $66.4 \%$ of students regularly had the main meal with their parents or guardians (Table 1).

We observed that $19.2 \%$ of participants reported regular consumption of sweets and soft drinks, $36.1 \%$ regularly consumed one of these sugar-rich foods, and $44.7 \%$ consumed these foods irregularly (Table 2). Regular consumption of sweets and soft drinks was more prevalent among female adolescents, those with higher levels of maternal education, those that did not live with their mother and father, who had meals with parents/guardians irregularly, that eat meals while watching TV and that spend more time watching television per day (Table 3 ).

The ordinal multiple regression analysis showed that the odds of regularly consuming sweets or/and soft drinks was higher among females; adolescents aged 14 and 15; students with mothers with higher education and those who did not know or report on their mother's education; adolescents that do not live with their mother and father; those who have meals irregularly with parents/guardians; those that eat meals in front of the TV; and those with a high amount of daily TV time. The largest magnitudes of association with the outcome variable were found for maternal education $\geq 12$ years $(\mathrm{OR}=1.29)$, being female $(\mathrm{OR}=1.36)$, eating while watching $\mathrm{TV}(\mathrm{OR}=$ 1.44) and time spent watching TV $\geq 5$ hours per day $(\mathrm{OR}=1.82)$, highlighting the clear association gradient observed between daily time spent watching television and regular consumption of sweets and soft drinks (Table 4).

\section{Discussion}

This was the first study to analyze the prevalence of combined consumption of sweets and soft drinks in a representative sample of adolescents living in urban and rural areas in Brazil, and to identify the different factors associated with consumption of these foods. The frequency of consumption of sugar-rich food products among Brazilian adolescents was alarming. Almost onefifth of adolescents regularly consumed sweets and soft drinks, and more than one third of them reported regular consumption of one of these sugar-rich foods products. Gender, age, maternal education, not living with their mother and father, having meals irregularly with parents/ guardians, eating in front of the TV, and a high amount of time spent watching television influenced the prevalence of consumption of sugarrich food products.

A comparison between these findings and those of other studies is hampered due to the distinct methodologies used to assess food consumption and in determining the categories of analysis. However, it is important to highlight that our observations are consistent with studies performed in other countries, which reported elevated consumption of sugar-rich food products among adolescents, specifically soft drinks, candies, and desserts 2,4,6,9,22.

The relevance of the data obtained in this study resides, above all, in the relationship between the consumption of sugar-rich food products in adolescence and the emergence and aggravation of overweight and co-morbidities, whose prevalence in several countries reached disturbing levels in the last decades 5,23 . This association is related not only to the high calorie content of these foods, but also because it favors the consumption of other foods with high energy density, such as fast food, and due to the replacement of the consumption of healthier foods, especially milk, fruits and vegetables ${ }^{5}$. It is important to note that in the United States, where obesity is prevalent in nearly $17 \%$ of adolescents 24 (in Brazil the prevalence is $4.9 \%$ ) $25,27.8 \%$ of its 
Socio-demographic, behavioral, and family-related characteristics of Brazilian students. National School Health Survey (PeNSE). Brazil, 2012.

\begin{tabular}{|c|c|}
\hline Variables & $\%(95 \% \mathrm{Cl})$ \\
\hline \multicolumn{2}{|l|}{ Gender } \\
\hline Male & $47.8(45.8-49.8)$ \\
\hline Female & $52.2(50.2-54.2)$ \\
\hline \multicolumn{2}{|l|}{ Age (years) } \\
\hline$\leq 13$ & $22.9(17.6-29.3)$ \\
\hline 14 & $45.6(42.5-48.7)$ \\
\hline 15 & $18.4(14.7-22.7)$ \\
\hline$\geq 16$ & $13.2(9.1-18.7)$ \\
\hline \multicolumn{2}{|l|}{ Skin color } \\
\hline White & $36.8(31.7-42.2)$ \\
\hline Black & $13.3(11.2-15.8)$ \\
\hline Brown & $42.2(39.1-45.4)$ \\
\hline Asian & $4.1(3.5-4.9)$ \\
\hline American Indian & $3.5(2.8-4.4)$ \\
\hline \multicolumn{2}{|c|}{ Maternal education (years) } \\
\hline$\leq 8$ & $42.3(39.4-45.3)$ \\
\hline $9-11$ & $26.0(23.2-29.0)$ \\
\hline$\geq 12$ & $13.3(12.1-14.5)$ \\
\hline Do not know & $18.4(17.9-18.9)$ \\
\hline \multicolumn{2}{|c|}{ Administrative classification of the school } \\
\hline Public & $82.8(77.8-86.9)$ \\
\hline Private & $17.2(13.1-22.2)$ \\
\hline \multicolumn{2}{|c|}{ Lives with mother and father } \\
\hline Yes & $62.2(60.2-64.2)$ \\
\hline No & $37.8(35.8-39.8)$ \\
\hline \multicolumn{2}{|c|}{ Habit of having meals with parents/guardians } \\
\hline Regular * & $66.4(64.4-68.4)$ \\
\hline Irregular ** & $33.6(31.6-35.6)$ \\
\hline \multicolumn{2}{|c|}{ Eating while watching television } \\
\hline No & $18.9(16.6-21.3)$ \\
\hline Yes & $81.1(78.7-83.4)$ \\
\hline \multicolumn{2}{|c|}{ Time spent watching TV (hours/day) } \\
\hline$\leq 2$ & $36.3(35.5-37.2)$ \\
\hline $3-4$ & $27.1(26.3-27.9)$ \\
\hline$\geq 5$ & $36.6(35.0-38.1)$ \\
\hline
\end{tabular}

95\% Cl: 95\% confidence interval.

* Four days or less per week;

** Five or more days per week.

population drinks soft drinks daily23, and female adolescents consume sweets an average of 2.4 times per week 26 . The finding that nearly onefifth of Brazilian students regularly consume both soft drinks and sweets, given the similarity of the scenario in the United States, is thus alarming. Therefore, the identification of factors that influence this ingestion is vital in order to avoid obesity rates among Brazilian adolescents reaching such elevated numbers and even more severely affecting the health of this population.

Despite the idea that female adolescents are, in general, more concerned than male adolescents with food consumption in order to control their weight 27 and that they are more frequently responsible for buying and preparing the food 
Consumption of sugar-rich food products among Brazilian students. National School Health Survey (PeNSE). Brazil, 2012.

\begin{tabular}{ll}
\hline Consumption of sugar-rich food products & $\%(95 \% \mathrm{Cl})$ \\
\hline Do not consume sweets and soft drinks regularly * & $44.7(43.1-46.4)$ \\
Consume sweets or soft drinks regularly ** & $36.1(34.7-37.4)$ \\
Consume sweets and soft drinks regularly ** & $19.2(18.4-20.1)$ \\
\hline $95 \% \mathrm{Cl}: 95 \%$ confidence interval. & \\
* Four days or less per week; &
\end{tabular}

they ingest 14,27,28, we observed a higher frequency of sugar-rich food product consumption among female adolescents. A similar scenario was reported in a study based on data from PeNSE 2009, conducted with adolescents living in Brazilian capitals and the Federal District, which indicated that female adolescents consumed cookies and food like sausages more frequently, in addition to reporting a lower frequency of consumption of beans and milk 29 . Moreover, a study that used data from PeNSE 2012 showed a poorer quality diet among girls compared with boys 30 , suggesting that Brazilian female adolescents are more exposed to inadequate food consumption 29,30.

The finding regarding the association gradient between a higher amount of time spent watching TV and more elevated consumption of sugar-rich food products among adolescents is also consistent with evidence from other studies $17,31,32,33,34$. Evidence suggests that behavioral risk factors, such as the habit of watching $\mathrm{TV}$, or lengthy screen time, and inadequate food consumption, have an influence on one another, tending to coexist in the form of a cluster, resulting in added risk of the development of overweight and comorbidities 32 . This coexistence can be justified by the elevated exposure of adolescents with higher screen time to advertisements of food products with elevated calorie content, such as sweets and soft drinks, favoring the consumption of those food groups instead of products with less media exposure, such as fruits and vegetables 14,17,31.

Moreover, the habit of eating while watching television has been pointed to as one of the main mediators of the association between screen time and inadequate food consumption among adolescents. TV and other electronic devices, serve as a distraction during meals, encouraging the excessive ingestion of calories, particularly of products ready for consumption 17,33. Children and adolescents who eat while watch- ing TV are, in general, found to have a higher consumption of soft drinks and fast food, and a lower consumption of fruits and vegetables 16,17. Given that in this study the largest magnitudes of association with the regular consumption of sugar-rich food products accounted for factors related to television (the habit of eating in front of the TV and the amount of time watching TV daily), this reinforces the relevance of interventions that involve multiple behaviors, including these aspects, since the improvement of one behavior can increase adolescent's self-efficacy and motivation to adopt other lifestyle changes, with additional health benefits 34 .

Regarding age, 14 and 15-year-old adolescents, for the entire population, and 14, 15 and 16-year-old adolescents among males, reported consuming sugar-rich food products more frequently in comparison with those who were aged 13 or under. Although a gradient of prevalence of consumption of sugar-rich food products was not observed with increasing age, the findings of this study are in agreement with the current evidence that older adolescents have more autonomy and more opportunities to select and buy food outside the home, which mainly consists of calorie-rich products, such as sweets and soft drinks 14,30 .

The association between higher levels of maternal education and regular consumption of sugar-rich food products possibly reflects the easier economic access to products that are ready to eat among these students, since this variable can be considered as a proxy of socioeconomic status 22,35. Studies performed with data from PeNSE 2009 found no association between regular consumption of soft drinks and sweets, evaluated separately, and maternal education ${ }^{29}$, nor of an unhealthy eating pattern with the Municipal Human Development Index (income, education and longevity) 36 . It emphasizes that the findings of this publication are supported by a study 
Table 3

Prevalence of regular consumption of sugar-rich food products among Brazilian students, according to socio-demographic, behavioral, and family-related data for total population. National School Health Survey (PeNSE). Brazil, 2012.

\begin{tabular}{|c|c|c|c|}
\hline \multirow[t]{3}{*}{ Variables } & \multicolumn{3}{|c|}{ Consumption of sugar-rich food products } \\
\hline & $\begin{array}{l}\text { Do not consume } \\
\text { sweets and soft } \\
\text { drinks regularly * }\end{array}$ & $\begin{array}{c}\text { Consume sweets or soft } \\
\text { drinks regularly ** }\end{array}$ & $\begin{array}{l}\text { Consume sweets and } \\
\text { soft drinks regularly ** }\end{array}$ \\
\hline & $\%(95 \% \mathrm{Cl})$ & $\%(95 \% \mathrm{Cl})$ & $\%(95 \% \mathrm{Cl})$ \\
\hline \multicolumn{4}{|l|}{ 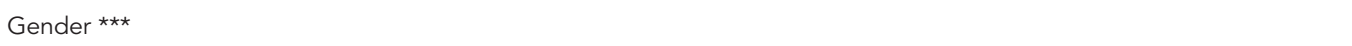 } \\
\hline Male & $49.1(47.4-50.8)$ & $34.4(33.2-35.6)$ & $16.5(15.7-17.2)$ \\
\hline Female & $40.7(38.7-42.7)$ & $37.6(35.9-39.3)$ & $21.7(20.7-22.8)$ \\
\hline \multicolumn{4}{|l|}{ Age (years) } \\
\hline$\leq 13$ & $45.3(43.1-47.5)$ & $36.2(34.5-37.9)$ & $18.5(17.6-19.4)$ \\
\hline 14 & $43.9(42.2-45.7)$ & $36.7(35.3-38.1)$ & $19.4(18.8-19.9)$ \\
\hline 15 & $43.6(41.4-46.0)$ & $35.6(34.0-37.3)$ & $20.7(19.2-22.3)$ \\
\hline$\geq 16$ & $47.9(44.9-50.8)$ & $34.3(33.3-35.4)$ & $17.8(15.4-20.4)$ \\
\hline \multicolumn{4}{|l|}{ Skin color } \\
\hline White & $44.9(42.6-47.3)$ & $35.9(34.6-37.3)$ & $19.2(18.0-20.4)$ \\
\hline Black & $44.6(42.4-46.8)$ & $35.3(33.3-37.4)$ & $20.1(19.5-20.7)$ \\
\hline Brown & $44.6(42.8-46.3)$ & $36.3(34.9-37.7)$ & $19.2(18.0-20.5)$ \\
\hline Asian & $42.7(40.6-44.7)$ & $39.2(38.2-40.2)$ & $18.1(16.5-19.9)$ \\
\hline American Indian & $47.3(45.5-49.0)$ & $34.7(32.8-36.7)$ & $18.0(15.4-21.0)$ \\
\hline \multicolumn{4}{|c|}{ 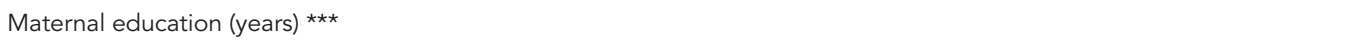 } \\
\hline$\leq 8$ & $46.8(44.3-49.3)$ & $35.6(34.0-37.1)$ & $17.7(16.5-18.9)$ \\
\hline $9-11$ & $43.3(41.8-44.9)$ & $36.7(35.1-38.3)$ & $20.0(19.5-20.6)$ \\
\hline$\geq 12$ & $41.7(40.7-42.8)$ & $36.7(34.9-38.6)$ & $21.5(20.5-22.6)$ \\
\hline Do not know & $44.1(42.6-45.6)$ & $36.0(34.5-37.5)$ & $20.0(19.1-20.9)$ \\
\hline \multicolumn{4}{|c|}{ Administrative classification of the school } \\
\hline Public & $45.2(43.1-47.3)$ & $35.8(34.4-37.3)$ & $18.9(18.0-19.9)$ \\
\hline Private & $42.3(41.3-43.3)$ & $37.2(35.6-38.8)$ & $20.5(19.0-22.1)$ \\
\hline \multicolumn{4}{|c|}{ 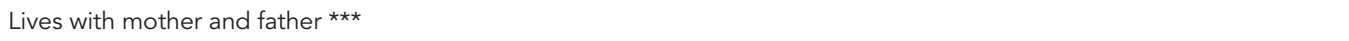 } \\
\hline Yes & $45.7(43.6-47.8)$ & $36.1(34.4-37.8)$ & $18.3(17.4-19.2)$ \\
\hline No & $43.1(42.1-44.1)$ & $36.1(35.1-37.2)$ & $20.8(20.0-21.5)$ \\
\hline \multicolumn{4}{|c|}{$\begin{array}{l}\text { Habit of having meals with parents/ } \\
\text { guardians } * \star \star\end{array}$} \\
\hline Regular * & $46.2(44.4-48.1)$ & $35.5(34.2-36.7)$ & $18.3(17.4-19.2)$ \\
\hline Irregular ** & $41.7(40.0-43.4)$ & $37.3(35.4-39.2)$ & $21.0(20.4-21.7)$ \\
\hline \multicolumn{4}{|c|}{ 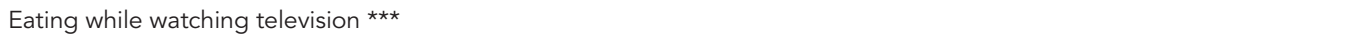 } \\
\hline No & $54.8(52.6-56.9)$ & $32.4(30.3-34.5)$ & $12.9(11.9-13.9)$ \\
\hline Yes & $42.4(40.7-44.1)$ & $36.9(35.7-38.2)$ & $20.7(19.9-21.5)$ \\
\hline \multicolumn{4}{|c|}{ 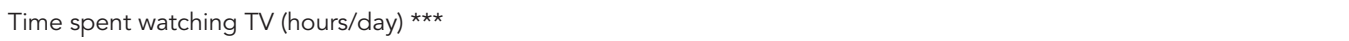 } \\
\hline$\leq 2$ & $52.7(51.2-54.1)$ & $33.0(31.9-34.1)$ & $14.4(13.4-15.4)$ \\
\hline $3-4$ & $45.3(42.2-48.4)$ & $37.2(35.2-39.3)$ & $17.5(16.3-18.6)$ \\
\hline$\geq 5$ & $36.3(35.0-37.7)$ & $38.3(37.0-39.6)$ & $25.4(24.4-26.3)$ \\
\hline
\end{tabular}

95\% Cl: $95 \%$ confidence interval;

* Four days or less per week;

** Five or more days per week;

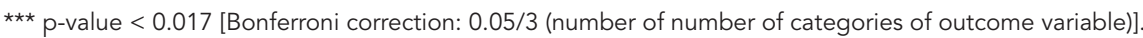


Variables associated with the regular consumption of sweets or/and soft drinks among Brazilian students by ordinal regression analysis. National School Health Survey (PeNSE). Brazil, 2012.

\begin{tabular}{|c|c|c|}
\hline \multirow[t]{2}{*}{ Variables } & \multicolumn{2}{|c|}{ Consumption of sugar-rich food products } \\
\hline & OR crude $(95 \% \mathrm{Cl})$ & OR adjusted $*(95 \% \mathrm{Cl})$ \\
\hline \multicolumn{3}{|l|}{ Gender } \\
\hline Male & 1.00 & 1.00 \\
\hline Female & $1.40(1.38-1.43)$ & $1.36(1.33-1.38)$ \\
\hline \multicolumn{3}{|l|}{ Age (years) } \\
\hline$\leq 13$ & 1.00 & 1.00 \\
\hline 14 & $1.06(1.02-1.09)$ & $1.08(1.03-1.12)$ \\
\hline 15 & $1.09(0.98-1.22)$ & $1.19(1.05-1.34)$ \\
\hline$\geq 16$ & $0.91(0.77-1.08)$ & $1.04(0.87-1.25)$ \\
\hline \multicolumn{3}{|l|}{ Skin color } \\
\hline White & 1.00 & $\star \star$ \\
\hline Black & $1.03(0.99-1.07)$ & \\
\hline Brown & $1.01(0.93-1.10)$ & \\
\hline Asian & $1.04(0.90-1.21)$ & \\
\hline American Indian & $0.91(0.79-1.06)$ & \\
\hline \multicolumn{3}{|c|}{ Maternal education (years) } \\
\hline$\leq 8$ & 1.00 & 1.00 \\
\hline 9-11 & $1.15(1.07-1.25)$ & $1.14(1.07-1.21)$ \\
\hline$\geq 12$ & $1.24(1.13-1.37)$ & $1.29(1.19-1.39)$ \\
\hline Do not know & $1.13(1.07-1.20)$ & $1.11(1.06-1.17)$ \\
\hline \multicolumn{3}{|c|}{ Administrative classification of the school } \\
\hline Public & 1.00 & 1.00 \\
\hline Private & $1.12(1.01-1.24)$ & $1.11(1.00-1.22)$ \\
\hline \multicolumn{3}{|c|}{ Lives with mother and father } \\
\hline Yes & 1.00 & 1.00 \\
\hline No & $1.13(1.08-1.17)$ & $1.06(1.03-1.09)$ \\
\hline \multicolumn{3}{|c|}{ Habit of having meals with parents/guardians } \\
\hline Regular & 1.00 & 1.00 \\
\hline Irregular & $1.20(1.14-1.26)$ & $1.12(1.07-1.18)$ \\
\hline \multicolumn{3}{|c|}{ Eating while watching television } \\
\hline No & 1.00 & 1.00 \\
\hline Yes & $1.67(1.60-1.75)$ & $1.44(1.38-1.50)$ \\
\hline \multicolumn{3}{|c|}{ Time spent watching TV (hours/day) } \\
\hline$\leq 2$ & 1.00 & 1.00 \\
\hline $3-4$ & $1.32(1.20-1.44)$ & $1.26(1.16-1.35)$ \\
\hline$\geq 5$ & $1.98(1.92-2.04)$ & $1.82(1.78-1.87)$ \\
\hline
\end{tabular}

95\% $\mathrm{Cl}$ : 95\% confidence interval; OR: odds ratio.

* Adjustment performed by all other variables of the study included in the final model (multiple ordinal regression model);

$\star \star$ Variable not included in the final model ( $p$-value $>0.05$ ).

developed with Chinese adolescents 36, but are contrary to the results of a study conducted in the United States, where the consumption of soft drinks was more frequent among adolescents with lower purchasing power ${ }^{37}$. This observation is in accordance with the trend, already identified in low- and middle-income countries, including
Brazil, of gradual substitution of foods rich in complex carbohydrates and fibers for products with higher calorie contents, rich in sugar and fat, as the socioeconomic conditions of the families improve 14,38. Indeed, in Eastern European countries and the Baltic States, which are mostly middle-income countries, the consumption of 
soft drinks has been regarded as an indicator of wealth 14 .

In addition, the relationship between family context factors and the consumption of foods that are high in sugar content highlights the importance of the social environment in the adoption of health behaviors by adolescents. Studies suggest that adolescents who do not live with their mother and father have an increased chance of having several risk behaviors, including smoking, alcohol and other drugs use, and sedentary behavior 15,31. This relationship derives from a possible lack of support and adequate monitoring of adolescents who do not live with their parents 15,31 . Having meals in the presence of parents/ guardians encourages family cohesion, since it favors moments of interaction among its members, in addition to providing lower consumption of fried foods and soft drinks and a higher intake of dairy and fruits and vegetables 15,29,30,39.

The use of a self-completed questionnaire for data collection could lead to imprecision or errors in the measurement of food intake. In this sense, analyses carried out before the completion of this study to evaluate the quality and validity of the questionnaire pointed to the suitability of the terms used and the validity of the estimated results 15,31 , including a high accuracy of indicators of food intake 40 . It is important also to consider that the question used for the measurement of soft drink consumption does not identify the type of soft drink consumed. Thus, among students who regularly consumed such drinks, there may be individuals who consumed a diet/light/zero version, which does not constitute a sugar-rich food product. Nevertheless, according to PeNSE 2009 in Brazilian capitals and the Federal District, when considering students who reported consumption of soft drinks in the seven days preceding the survey, intake of sugarfree soft drinks accounted for only $9.5 \%$ (data not shown). Thus, results presented about consumption of this drink should be analyzed taking into account this limitation.

Another possible limitation of this study relates to the higher percentage of boys and adolescents over the age of 16 among non-respondents to the questions related to the consumption of sweets and soft drinks, which, despite the small percentage of non-responses, may have affected the results. A high percentage of adolescents who did not respond to questions about maternal education also might have affected the findings. However, even without this information, we observed an association gradient between the higher level of the mother's education and regular consumption of sugar-rich food products, which suggests the importance of this variable to the frequency of consumption of these foods. In addition, a response of not knowing about maternal education levels was found to be associated with a higher frequency of regular consumption of soft drinks and sweets, leading us to assume that this non-response may result from the fact that mothers only had non-formal education, making it difficult to give an exact response to the question about years of study, or may reflect a limited link between the adolescent and his mother. This hypothesis was based on the finding that the percentage of non-respondents to the question of maternal education was higher among those who reported not living with their mother $(23.9 \%$ vs. $17.9 \%$ ) and not having meals with parents/ guardians (19.5\% vs. $17.9 \%$ ) (data not shown).

This study restricted its analysis to the consumption of sweets and soft drinks as sugar-rich food products and does not address other foods belonging to this group, such as confectionery and other sweetened beverages, whose regular consumption can also interfere with the health and nutrition of adolescents. In this sense, within the group "sweets", several types of foods were considered including candies, chocolate, chewing gum, bonbons and lollipops, comprising therefore a variable with considerable scope. Although studies developed in different countries have shown that soft drinks consist of the main sweetened beverage consumed by adolescents, consisting of a good indicator of intake of sweetened beverages in this age group 6,37, the evaluation of consumption of other sweetened beverages was thought to complement the analysis of the intake of sugar-rich food products among Brazilian adolescents. In this regard, a study conducted in Rio de Janeiro, Brazil, found that $33.3 \%$ of students consumed soft drinks regularly, while $66.2 \%$ reported regular consumption of sweetened beverages, including soft drinks ${ }^{40}$, thus demonstrating the relevance of the analysis of different sweetened beverages among adolescents.

The novelty of the current research is that it constitutes a pioneering study, evaluating combined consumption of sweets and soft drinks using a representative sample of adolescents enrolled in the ninth grade of public and private schools of all regions of Brazil, including urban and rural areas. It is noteworthy that many studies evaluate only the consumption of soft drinks individually, not together with the ingestion of sweets, hindering the analysis of accumulated consumption of sugar-rich food products and its associated factors 5,6,18,20,22.

In conclusion, the present data reveal an alarming scenario concerning the combined consumption of sweets and soft drinks, which 
was reported by nearly one-fifth of the Brazilian students. This consumption was associated with gender, age, maternal education and not living with their mother and father. Moreover, modifiable factors were also related to the consumption of sweets and soft drinks, including the habit of having meals with parents/guardians irregularly, eating meals in front of the TV and time spent daily watching television. Changing these factors should therefore be a priority for interventions that aim to contribute to the improvement of food consumption among Brazilian students. Thus, we believe that the identification of factors that stimulate the accumulated consumption of sugar-rich food products among Brazilian adolescents that are subject to changes might contribute to the drawing up of public policies that aim to reduce this eating habit. This would therefore prevent negative health effects, particularly overweight and associated morbidities, both in the present and in their future adult lives.

\section{Resumen}

Se tuvo como objetivo analizar el consumo de alimentos ricos en azúcar entre estudiantes brasileños e identificar sus factores asociados. Se utilizaron datos de la Encuesta Nacional de Salud Escolar (PeNSE 2012). El consumo de estos alimentos fue clasificado como: no consumen golosinas/refrescos regularmente; consumen golosinas o refrescos regularmente; consumen golosinas y refrescos regularmente. Factores sociodemográficos, alimentarios y familiares asociados fueron evaluados por regresión ordinal múltiple. El consumo regular de golosinas y/o refrescos fue relatado por 19,2\% y 36,1\% de los adolescentes, respectivamente, siendo más prevalente entre estudiantes del sexo femenino, con 14-15 años de edad, con mayor escolaridad materna, que no vivían con la madre y el padre, que no realizan las comidas con los padres, que comían viendo TV y que pasaban más tiempo viendo TV. Casi 1/5 de los adolescentes consumía golosinas y refrescos regularmente, condición asociada a factores sociodemográficos y de comportamiento, que deben ser observados como prioridad para mejorar el consumo alimenticio.

Nutrición del Adolescente; Consumo de Alimentos; Salud Escolar; Azúcar; Gaseosas

\section{Contributors}

N. L. Ferreira participated in the design of the study, performed the statistical analysis, data interpretation and wrote the manuscript, read and approved the final manuscript. R. M. Claro and A. C. S. Lopes contributed in the design of the study, provided statistical expertise and reviewed critically the initial versions of the manuscript, read and approved the final manuscript.

\section{Acknowledgments}

The authors wish to thank the Office of the Dean for Research, Federal University of Minas Gerais (PRPq/ UFMG) for the English translation of this manuscript. 


\section{References}

1. Ministério da Saúde. Saúde do adolescente: competências e habilidades. Brasília: Ministério da Saúde; 2008.

2. Gómez-Martínez S, Martínez-Gómez D, Perez de Heredia F, Romeo J, Cuenca-Garcia M, Martín-Matillas M, et al. Eating habits and total and abdominal fat in Spanish adolescents: influence of physical activity: The AVENA study. J Adolesc Health 2012; 50:403-9.

3. Departamento de Atenção Básica, Secretaria de Atenção à Saúde, Ministério da Saúde. Guia alimentar para a população brasileira. 2ạ Ed. Brasília: Ministério da Saúde; 2014.

4. Nielsen SJ, Popkin BM. Patterns and trends in food portion sizes, 1977-1998. JAMA 2003; 289:450-3.

5. Denney-Wilson E, Crawford D, Dobbins T, Hardy L, Okely AO. Influences on consumption of soft drinks and fast foods in adolescents. Asia Pac J Clin Nutr 2009; 18:447-52.

6. Duffey KJ, Huybrechts I, Mouratidou T, Libuda L, Kersting M, De Vriendt T, et al. Beverage consumption among European adolescents in the HELENA study. Eur J Clin Nutr 2012; 66:244-52.

7. Instituto Brasileiro de Geografia e Estatística. Pesquisa de orçamentos familiares 2008-2009: análise do consumo alimentar pessoal no Brasil. Rio de Janeiro: Instituto Brasileiro de Geografia e Estatística; 2011.

8. Welsh JA, Sharma A, Cunningham SA, Vos MB. Consumption of added sugars and indicators of cardiovascular disease risk among US adolescents. Circulation 2011; 123:249-57.

9. Zanini RV, Muniz LC, Schneider BC, Tassitano RM, Feitosa WMN, González-Chica DA. Consumo diário de refrigerantes, doces e frituras em adolescentes do Nordeste brasileiro. Ciênc Saúde Coletiva 2013; 18:3739-50.

10. Castro IRR, Cardoso LO, Egstrom EM, Levy RB, Monteiro CA. Vigilância de fatores de risco para doenças não transmissíveis entre adolescentes: a experiência da cidade do Rio de Janeiro, Brasil. Cad Saúde Pública 2008; 24:2279-88.

11. Malik SV, Schulze MB, Hu FB. Intake of sugarsweetened beverages and weight gain: a systematic review. Am J Clin Nutr 2006; 84:274-88.

12. Morton KL, Wilson AH, Perlmutter LS, Beauchamp MR. Family leadership styles and adolescent dietary and physical activity behaviors: a cross-sectional study. Int J Behav Nutr Phys Act 2012; 9:48.

13. World Health Organization. Guideline: sugars intake for adults and children. Geneva: World Health Organization; 2015.

14. Currie C, Zanotti C, Morgan A, Currie D, Looze M, Roberts C, et al. Social determinants of health and well-being among young people. Health Behaviour in School-aged Children (HBSC) study: international report from the 2009/2010 survey. Copenhagen: WHO Regional Office for Europe; 2012. (Health Policy for Children and Adolescents, 6).

15. Instituto Brasileiro de Geografia e Estatística. Pesquisa Nacional de Saúde do Escolar - 2012. Rio de Janeiro: Instituto Brasileiro de Geografia e Estatística; 2013.
16. Centers for Disease Control and Prevention. School health guidelines to promote healthy eating and physical activity. Washington DC: Centers for Disease Control and Prevention; 2011.

17. Gebremariam MK, Bergh IH, Andersen LF, Ommundsen Y, Totland TH, Bjelland M, et al. Are screen-based sedentary behaviors longitudinally associated with dietary behaviors and leisure-time physical activity in the transition into adolescence? Int J Behav Nutr Phys Act 2013; 10:9.

18. Hebden L, Hector D, Hardy LL, King L. A fizzy environment: availability and consumption of sugarsweetened beverages among school students. Prev Med 2013; 56:416-8.

19. Conceição SIO, Santos CJN, Silva AAM, Silva JS, Oliveira TC. Consumo alimentar de escolares das redes pública e privada de ensino em São Luís, Maranhão. Rev Nutr 2010; 23:993-1004.

20. Bogart LM, Cowgill BO, Sharma AJ, Uyeda K, Sticklor LA, Alijewicz KE, et al. Parental and home environmental facilitators of sugar-sweetened beverage consumption among overweight and obese Latino youth. Acad Pediatr 2013; 13:348-55.

21. Abreu MNS, Siqueira AL, Caiaffa WT. Regressão logística ordinal em estudos epidemiológicos. Rev Saúde Pública 2009; 43:183-94.

22. Ortiz-Hernández L, Gómez-Tello BL. Food consumption in Mexican adolescents. Rev Panam Salud Pública 2008; 24:127-35.

23. Centers for Disease Control and Prevention. Trends in the prevalence of obesity, dietary behaviors, and weight control practices national YRBS: 1991-2011. Washington DC: Centers for Disease Control and Prevention; 2011.

24. Ogden CL, Carrol MD, Kit BK, Flegal KM. Prevalence of childhood and adult obesity in the United States, 2011-2012. JAMA 2014; 311:806-14.

25. Instituto Brasileiro de Geografia e Estatística. Pesquisa de orçamentos familiares 2008-2009: antropometria e estado nutricional de crianças, adolescentes e adultos no Brasil. Rio de Janeiro: Instituto Brasileiro de Geografia e Estatística; 2010.

26. Cohen DA, Ghosh-Dastidar B, Beckman R, Lytle L, Elder J, Pereira MA, et al. Adolescent girls' most common source of junk food away from home. Health Place 2012; 18:963-70.

27. Kanaan MN, Afifi RA. Gender differences in determinants of weight-control behaviours among adolescents in Beirut. Public Health Nutr 2009; 13: 71-81.

28. Herscovici CR, Kovalskys I, De Gregorio MJ. Gender differences and a school-based obesity prevention program in Argentina: a randomized trial. Rev Panam Salud Pública 2013; 34:75-82.

29. Levy RB, Castro IRR, Cardoso LO, Tavares LF, Sardinha LMV, Gomes FS, et al. Consumo e comportamento alimentar entre adolescentes brasileiros: Pesquisa Nacional de Saúde do Escolar (PeNSE), 2009. Ciênc Saúde Coletiva 2010; 15 Suppl 2: 3085-97.

30. Azeredo CM, Rezende LFM, Canella DS, Claro RM, Castro IRR, Luiz OC, et al. Dietary intake of Brazilian adolescents. Public Health Nutr 2014; 18: 1215-24. 
31. Camelo LV, Rodrigues JFC, Giatti L, Barreto SM. Lazer sedentário e consumo de alimentos entre adolescentes brasileiros: Pesquisa Nacional de Saúde do Escolar (PeNSE), 2009. Cad Saúde Pública 2012; 28: 2155-62.

32. Driskell MM, Dyment S, Mauriello L, Castle P Sherman K. Relationships among multiple behaviors for childhood and adolescent obesity prevention. Prev Med 2008; 46:209-15.

33. Pearson N, Ball K, Crawford D. Mediators of longitudinal associations between television viewing and eating behaviours in adolescents. Int J Behav Nutr Phys Act 2011; 8:23.

34. Pearson N, Atkin AJ, Biddle S, Gorely T, Edwardson C. Patterns of adolescent physical activity and dietary behaviours. Int J Behav Nutr Phys Act 2009; $6: 45$.

35. Shi Z, Lien N, Kumar BN, Holmboe-Ottesen G. Socio-demographic differences in food habits and preferences of school adolescents in Jiangsu Province, China. Eur J Clin Nutr 2005; 59:1439-48.

36. Tavares LF, Castro IRR, Levy RB, Cardoso LO, Claro RM. Dietary patterns of Brazilian adolescents: results of the Brazilian National School-Based Health Survey (PeNSE). Cad Saúde Pública 2014; 30:2679-90.
37. Han E, Powell LM. Consumption patterns of sugar sweetened beverages in the United States. J Acad Nutr Diet 2013; 113:45-53.

38. Neutzling MB, Araújo CLP, Vieira MFA, Hallal PC, Menezes AMB. Frequência de consumo de dietas ricas em gordura e pobres em fibra entre adolescentes. Rev Saúde Pública 2007; 41:336-42.

39. Chan JC, Sobal J. Family meals and body weight. Analysis of multiple family members in family units. Appetite 2011; 57:517-24.

40. Tavares LF, Castro IRR, Levy RB, Cardoso LO, Passos MD, Brito FSB. Validade relativa de indicadores de práticas alimentares da Pesquisa Nacional de Saúde do Escolar entre adolescentes do Rio de Janeiro, Brasil. Cad Saúde Pública 2014; 30:1029-41.

Submitted on $02 / \mathrm{Feb} / 2015$

Final version resubmitted on 28/Jun/2015

Approved on $01 / \mathrm{Jul} / 2015$ 